\title{
Analisis Faktor “Pemicu” Minat Melakukan Whistleblowing
}

\author{
Aida Nahar* \\ Universitas Islam Nahdlatul Ulama \\ Kabupaten Jepara, Jawa Timur, Indonesia \\ E-mail: aida@unisnu.ac.id
}

\begin{abstract}
Abstrak
Penelitian ini bertujuan untuk menganalisis faktor yang menjadi pemicu munculnya minat pegawai untuk melakukan whistleblowing. Populasi dalam penelitian ini adalah pegawai yang bekerja di OPD sebagai sub bagian keuangan dan satu staf bagian keuangan seluruh Organisasi Perangkat Daerah (OPD) kabupaten Jepara dengan menggunakan simple random sampling. Hasil penelitian menunjukan bahwa faktor pemicu munculnya minat pegawai melakukan whistleblowing adalah faktor sikap pegawai, komitmen organisasi, personal cost dan tingkat keseriusan kecurangan pegawai. Semakin baik sikap pegawai yang ditunjukkan dengan sikap setuju untuk mengungkap tindakan kecurangan, maka semakin besar minat seseorang untuk melakukan tindakan whistleblowing. Semakin besar komitmen pegawai terhadap suatu organisasi, maka semakin besar minat pegawai untuk mengungkap kecurangan yang terjadi atau disebut dengan whistleblowing. Semakin tinggi resiko yang dihadapi oleh pegawai yang ditunjukkan dengan tingginya personal cost untuk mengungkap terjadinya kecurangan, maka semakin rendah minat pegawai untuk melaporkan tindakan kecurangan atau rendahnya minat untuk melakukan tindakan whistleblowing. Selain itu, semakin tinggi tingkat keseriusan memberantas kecurangan, maka semakin tinggi minat pegawai untuk mengungkap kecurangan tersebut kepada pihak berwenang dengan menjadi whistle-blower yang mempunyai arti besar pula minat pegawai untuk melakukan tindakan whistleblowing.
\end{abstract}

Kata Kunci: Komitmen Organisasi, whistleblowing, Personal Cost, Sikap, Tingkat Keseriusan Kecurangan.

\begin{abstract}
This study aims to analyze the factors that trigger employee interest in whistleblowing. The population in this study were employees who worked in the OPD as a financial subdivision and one financial staff member from all Regional Apparatus Organizations $(O P D)$ in Jepara Regency using simple random sampling. The results showed that the factors that triggered employee interest in whistleblowing were employee attitudes, organizational commitment, personal costs and the seriousness level of employee fraud. The better the employee's attitude which is shown by agreeing to disclose the fraud, the greater the person's interest in taking whistleblowing. The greater the employee's commitment to an organization, the greater the employee's interest in uncovering the fraud or in whistleblowing. The higher the risk faced by employees as indicated by the high personal cost to reveal the occurrence of fraud, the lower the employee's interest in reporting fraud or the lower the interest in whistleblowing. In addition, the higher the seriousness level in eradicating fraud, the higher the employee's interest in exposing the fraud to the authorities by becoming a whistle-blower, which also means that employees' interest in taking whistleblowing action will be higher.
\end{abstract}

Keywords: attitude; Organizational Commitment; Personal Cost; The seriousness level of fraud; whistleblowing

\section{Pendahuluan}

Beberapa tahun belakangan ini, terungkap meningkatnya tindak kecurangan dalam bentuk apapun di berbagai sektor baik sektor swasta maupun di sektor pemerintahan yang mendapat perhatian yang sangat serius dari publik. Terkhusus lagi yang terjadi pada sektor publik yang ada di Indonesia, bentuk kecurangan yang paling sensitif dan menjadi fokus perhatian publik adalah kecurangan dalam bentuk korupsi. Berdasarkan CPI (Corruption Perception Index) tahun 2020 yang diterbitkan oleh Transparency International Indonesia (TII) 2020, Indonesia berada pada skor 37 atau berada pada peringkat 102 dari 180 negara yang disurvei. Hasil tersebut menunjukkan bahwa masih tingginya persepsi korupsi di Indonesia.

Tingginya praktik koruptif dalam penyelenggaraan negara berdampak negatif bagi kesejahteraan masyarakat dan pembangunan di Indonesia (Oktavia, 2018). Kecurangan dalam bentuk korupsi selalu menimbulkan kerugian yang akan berdampak pada lambatnya pertumbuhan ekonomi pada suatu negara. Bibit korupsi yang semula kecil jika dibiarkan akan menjadi suatu kebiasaan buruk yang berbuah korupsi besar. Oleh sebab itu, pemberantasan korupsi dalam suatu organisasi dilakukan dengan cara mendeteksi korupsi terlebih dahulu. Salah satu cara pendeteksiannya dengan mengungkap tindakan kecurangan atau yang biasa disebut whistleblowing.

Whistleblowing merupakan sebuah tindakan mengungkap kasus-kasus korupsi yang terjadi di sebuah organisasi privat maupun organisasi publik kepada masyarakat (Kumar \& Santoro, 2017). Salah satu hal yang dapat dilakukan untuk mencegah terjadinya kasus korupsi atau tindakan pelanggaran yaitu dengan memberdayakan whistle-blower. Seorang pegawai suatu organisasi yang

\footnotetext{
* Corresponding author

e-Journal Ekonomi Bisnis dan Akuntansi, 2021, Volume 8 (1): 1-7
}

ISSN : 2355-4665 
mengungkap kasus kecurangan atau whistleblowing disebut dengan whistle-blower. Pengungkapan kecurangan yang dimaksud adalah tindakan mengetahui, menyaksikan, bahkan sampai melaporkan kejadian yang mengarah kejahatan atau penyimpangan yang dapat mengancam kepentingan masyarakat atau organisasi kemudian kejadian tersebut diungkap ke publik atau kepada pihak yang berwenang (Iskandar \& Saragih, 2018).

Setiap orang dapat menjadi whistle-blower, namun untuk menjadi seorang whistle-blower bukanlah sesuatu yang mudah. Tindakan tersebut membutuhkan suatu keberanian dan keyakinan. Seseorang yang berada dalam sebuah organisasi atau instansi umumnya mengalami dilematis dalam memutuskan apakah harus mengungkapkan atau membiarkan terjadinya tindakan kecurangan (Bagustianto \& Nurkholis, 2015). Bagi beberapa orang yang menjadi whistle-blower akan dipandang sebagai penghianat perusahaan karena telah mengungkap rahasia perusahaan, namun sebagian orang juga akan memandangnya sebagai pahlawan yang menjunjung tinggi nilai-nilai moral yang dianggap lebih penting daripada loyalitas kepada organisasi. Perbedaan pandangan tersebut sering menjadikan para calon whistle-blower dilema dan dapat membuat mereka mengurungkan niat untuk melakukan tindakan whistleblowing.

Penelitian ini dilakukan untuk menguji empat faktor pemicu yaitu sikap, komitmen organisasi, personal cost, keseriusan kecurangan dalam mempengaruhi minat pegawai yang bertugas sebagai pengelola keuangan Organisasi Perangkat Daerah (OPD) Kabupaten Jepara. Oleh karena itu, rumusan masalah dalam penelitian ini adalah faktor apa saja yang memicu minat pegawai untuk melakukan tindakan whistleblowing dengan menganalisis faktor sikap pegawai, komitmen organisasi pegawai, personal cost dan tingkat keseriusan tindakan kecurangan yang terjadi.

\section{Kajian Teori}

\section{Tinjauan Teori sosial Psikologi}

Penelitian ini menggunakan teori sosial psikologi Theory of Planned Behaviour (TPB) dan Prosocial Organizational Behavior Theory. Teori ini digunakan sebagai "pisau" analisis untuk meneliti tentang minat seseorang untuk berperilaku. Theory of Planned Behaviour (TPB) merupakan salah satu teori psikologi yang direview oleh Ajzen (1991) dengan didukung oleh bukti secara empiris. Teori ini mengungkap bahwa niat untuk melakukan berbagai jenis perilaku seseorang atau yang disebut dengan minat, dapat diprediksi dengan sikap seseorang dalam berperilaku.

Ajzen (1991) mengungkap bahwa minat merupakan usaha yang dilakukan seseorang baik terencana maupun tidak untuk mencoba melakukan sebuah perilaku. Minat merupakan suatu dorongan yang mempengaruhi perilaku seseorang. Orang akan berperilaku dipicu oleh tiga hal, antara lain, pertama, sikap atau yang disebut oleh Ajzen (1991) attitude toward behavior. Seseorang akan berperilaku dengan melakukan evaluasi dan menilai apakah perilaku yang akan dilakukan itu menguntungkan atau tidak. Kedua, subjective norm. Seseorang akan berperilaku jika ada tekanan sosial yang berasal dari norma yang ada di lingkungan. Dan pemicu ketiga adalah perceived behavioral control. Seseorang akan berperilaku dengan mempertimbangkan faktor kemudahan atau kesulitan untuk melakukan tindakan. Dari ketiga pemicu tersebut, menurut Ajzen (1991) terdapat tingkatan dan situasi yang berbeda-beda antara satu orang dengan orang lain yang pada akhirnya hanya sikap yang akan mempengaruhi minat seseorang untuk berperilaku.

Teori sosial psikolog yang kedua dalam penelitian ini adalah prosocial organizational Behavior theory. Teori ini dipelopori oleh Brief \& Motowidlo (1986) yang mengungkap bahwa seseorang melakukan tindakan atau berperilaku bertujuan untuk meningkat kesejahteraan baik untuk individu, kelompok maupun organisasi. Seseorang akan berperilaku jika memberikan manfaat atau keuntungan untuk orang lain dan untuk diri sendiri.

Minat seseorang untuk melakukan whistleblowing terjadi karena dipengaruhi oleh sikap seseorang yang terdorong untuk melakukan whistleblowing. Selain itu minat melakukan tindakan whistleblowing dilakukan karena menurut orang yang melakukan tersebut, akan bermanfaat untuk kemajuan suatu organisasi yang akhirnya akan bermanfaat pula untuk diri orang yang melaporkan atau disebut dengan wistle-blower.

\section{Sikap terhadap Wistleblowing.}

Sikap terhadap whistleblowing merupakan penilaian seseorang atas suatu tindakan/perilaku tertentu yang terjadi didasarkan pada seberapa setuju atau tidak setuju untuk melakukan tindakan atau perilaku tersebut (Bagustianto \& Nurkholis, 2015; Park \& Blenkinsopp, 2009). Karyawan atau pegawai akan menilai seberapa baik tindakan whistleblowing. Penilaian tersebut dilakukan untuk memutuskan apakah tindakan tersebut akan dilakukan atau tidak. Jika penilaiannya negatif atau akan berdampak buruk untuk diri sendiri atau organisasi, maka tindakan whistleblowing tidak akan dilakukan, begitu sebaliknya.

Menurut Secord \& Backman (1964) dan Bagustianto \& Nurkholis (2015), sikap seseorang terkait tindakan whistleblowing dibentuk oleh tiga komponen. Pertama, sikap atas suatu tindakan terbentuk dari pengetahuan dan keyakinan seseorang untuk melakukannya. Pengetahuan dan keyakinan seseorang ini disebut dengan komponen kognitif. Kedua, sikap atas suatu tindakan terbentuk atas dasar perasaan senang atau tidak senang. Komponen perasaan senang atau tidak senang disebut dengan komponen afektif. Jika perasaan seseorang senang untuk melakukannnya, maka orang tersebut akan terdorong untuk melakukan tindakan whistleblowing, namun jika seseorang merasa tidak senang akan tindakan whistleblowing, maka orang tersebut tidak akan melakukan tindakan whistleblowing.

Sedangkan komponen ketiga yang membentuk sikap atas tindakan whistleblowing adalah komponen konatif. Sikap seseorang atas suatu tindakan didasari oleh kesiapan atau kecenderungan untuk bertingkah laku. Jika seseorang memiliki kesiapan dan cenderung untuk lebih meyakini bahwa tindakan tersebut harus dilakukan, maka tindakan whistleblowing akan dilakukan, namun jika seseorang mempunyai keyakinan bahwa tindakan whistleblowing 
tidak baik untuk dilakukan, maka tindakan whistleblowing tidak akan terlaksana. Persepsi seseorang akan mempengaruhi Sikap untuk melakukan suatu tindakan. Hal ini sesuai dengan theory of panned behavior yang menyebutkan bahwa persepsi atau keyakinan seseorang dan penilaian yang bersifat subyektif atas dampak atau konsekuensi dari perilaku, akan mempengaruhi sikap seseorang untuk melakukan suatu tindakan.

Seseorang yang mempunyai persepsi bahwa melaporkan tindakan kecurangan itu adalah suatu perilaku yang baik dan harus dilakukan, maka semakin tinggi minat orang tersebut untuk melakukan tindakan whistleblowing, dan begitu sebaliknya. Sebagaimana hasil penelitian yang dilakukan oleh Bagustianto \& Nurkholis (2015) dan Sutrisni \& Coryanata (2018) menemukan bahwa sikap atas tindakan whistleblowing berpengaruh positif terhadap minat pengelola keuangan untuk melakukan tindakan whistleblowing. Oleh karena itu, hipotesis satu dalam penelitian ini adalah:

H1: Sikap terhadap whistleblowing berpengaruh positif terhadap minat pegawai melakukan tindakan whistleblowing.

\section{Komitmen Organisasi}

Komitmen organisasi merupakan sikap pegawai yang mengarah pada sikap positif untuk memajukan organisasi dengan cara mengungkap adanya tindakan kecurangan kepada pimpinannya sebagai bentuk keterlibatan pegawai dengan organisasi (Zubaidah, 2019). Meyer, Bobocel, \& Allen ( 1991) mengungkap bahwa Komitmen organisasi terdiri dari tiga model, pertama, Pegawai mengidentifikasi dan melibatkan diri dalam suatu organisasi. Keterlibatan ini disebut dengan komitmen afektif (Affective Commitment). Kedua, Aktivitas yang dilakukan oleh pegawai secara konsisten dan sungguh-sungguh yang secara sadar akan timbulnya biaya dan pengorbanan yang dikeluarkan yang akan berdampak pada kerugian yang akan ditanggung oleh perusahaan. Komitmen ini disebut dengan continuance commitment. Dan model yang ketiga, Pegawai sadar akan tanggung jawab atas kewajiban untuk menjalankan kegiatan suatu organisasi. Komitmen ini disebut dengan normative commitment.

Tingginya komitmen pegawai pada suatu organisasi, ditunjukkan dengan timbulnya rasa memiliki organisasinya (sense of belonging) yang berdampak pada keinginan dari pegawai untuk menjalankan organisasi secara berkelanjutan. Untuk menjalankan organisasi secara berkelanjutan, pegawai akan muncul minat untuk mengungkap semua tindakan yang akan merugikan organisasi. Hal ini dilakukan karena pegawai tersebut mempunyai keyakinan bahwa dengan mengungkap tindakan kecurangan, akan melindungi organisasi dari kehancuran, dan begitu sebaliknya. Hal ini sesuai dengan penelitian Bagustianto \& Nurkholis (2015) yang menemukan bahwa komitmen organisasi berpengaruh positif terhadap minat pegawai untuk melakukan tindakan whistleblowing. Oleh karena itu, hipotesis kedua dalam penelitian ini adalah:
H2: Komitmen organisasi berpengaruh positif terhadap minat pegawai melakukan tindakan whistleblowing.

\section{Personal Cost}

Personal cost merupakan risiko yang ditanggung pegawai sebagai konsekuensi dari pengungkapan tindakan kecurangan (Bagustianto \& Nurkholis, 2015; Schultz, Johnson, Morris, \& Dyrnes, 1993). Risiko yang ditanggung pegawai dapat berasal dari pelaku kecurangan yang dilaporkan yang akan berdampak pada balas dendam, namun dapat juga keputusan untuk melaporkan tindakan kecurangan merupakan tindakan yang tidak etis, karena berkaitan dengan tindakan yang dilakukan oleh pimpinan organisasi. Risiko tersebut dapat juga membahayakan keluarga dari pegawai yan melaporkan tindakan kecurangan atau berdampak pada anggota keluarga pegawai lainnya. Hal ini terjadi jika pelaku kecurangan mempunyai sikap pendendam yang tinggi dan memiliki sifat yang temperamental atau sikap yang tidak baik (Bagustianto \& Nurkholis, 2015).

Tingginya risiko yang ditanggung oleh pegawai sebagai akibat dari pengungkapan tindakan kecurangan, maka akan menurunkan minat pegawai untuk melakukan tindakan whistleblowing. Hal ini sesuai dengan penelitian Aliyah \& Marisan (2017) yang menemukan bahwa personal cost berpengaruh negative terhadap minat pegawai melakukan tindakan whistleblowing. Oleh karena itu, hipotesis ketiga dalam penelitian ini adalah:

H3: Personal cost berpengaruh negatif terhadap minat pegawai untuk melakukan tindakan whistleblowing.

\section{Tingkat Keseriusan Kecurangan.}

Tingkat keseriusan kecurangan merupakan persepsi pegawai atas besar kecilnya kecurangan yang terjadi (Bagustianto \& Nurkholis, 2015). Setiap pegawai mempunyai persepsi yag berbeda-beda atas besar kecilnya dampak dari kecurangan yang terjadi. Perbedaan persepsi berkaitan dengan besar kecilnya bentuk kecurangan dan jenis kecurangan.

Pegawai akan mempunyai minat mengungkap tindakan kecurangan, jika kecurangan yang terjadi akan berdampak serius pada suatu organisasi (Bagustianto \& Nurkholis, 2015; Miceli, Near, \& Schwenk, 1991). Semakin tinggi tingkat kecurangan yang berdampak pada kerugian suatu organisasi, maka semakin tinggi pula minat pegawai untuk melakukan tindakan whistleblowing. Hal ini sesuai dengan penelitiannya Aliyah \& Marisan (2017) dan Bagustianto \& Nurkholis (2015) yang menemukan bahwa tingkat keseriusan kecurangan berpengaruh positif terhadap minat pegawai untk melakukan tindakan whistleblowing. Oleh karena itu, hipotesis yang keempat dalam penelitian ini adalah

H4: Tingkat keseriusan kecurangan berpengaruh positif terhadap minat pegawai untuk melakukan tindakan whistleblowing. 
Berdasarkan ke empat hipotesis di atas, maka kerangka pemikiran teoritis dalam penelitian ini dapat digambarkan sesuai gambar 1 .

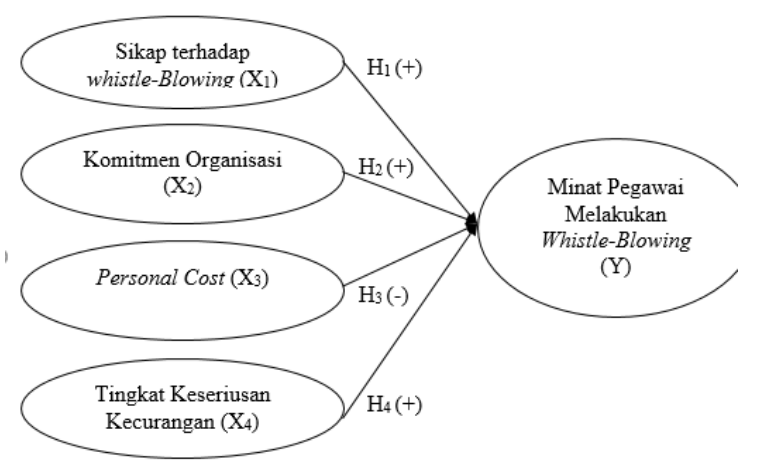

Gambar 1: Kerangka Pemikiran Teoritis

\section{Metode}

Penelitian ini menggunakan data primer yang diperoleh dengan menggunakan kuesioner yang terstruktur. Kuesioner dalam penelitian diambil dari beberapa peneliti terdahulu yang sesuai dengan variabel dalam penelitian ini. Variabel dependen dalam penelitian ini adalah minat pegawai melakukan tindakan whistleblowing yang didefiniskan oleh Aliyah \& Marisan (2017) sebagai Keinginan atau ketertarikan seseorang pada sesuatu sebelum melakukan tindakan whistleblowing secara actual. Indikator untuk menilai minat pegawai melakukan tindakan whistleblowing adalah niat/minat untuk melakukan tindakan whistleblowing, keinginan untuk mencoba melakukan tindakan whistleblowing, rencana untuk melakukan tindakan whistleblowing, usaha keras untuk melakukan internal whistleblowing, dan usaha keras untuk melakukan external whistleblowing, jika internal whistleblowing tidak memungkinkan.

Variabel independent dalam penelitian ini, antara lain sikap terhadap whistleblowing yang oleh Park \& Blenkinsopp (2009) dan Aliyah \& Marisan (2017) sebagai penilaian seseorang atas suatu perilaku atau tindakan tertentu dengan ditandai seberapa besar setuju atau tidak setujunya. Variabel sikap diukur dengan indikator melindungi organisasi dari dampak yang buruk akibat perilaku kecurangan, seberapa besar pendapat melawan korupsi, menjalankan kewajiban sebagai pegawai, serta menegakkan kewajiban etis dan keyakinan moral.

Variabel independent kedua adalah komitmen organisasi yang oleh Mowday, Steers, \& Porter (1979) mendefiniskan sebagai identifikasi dan keterlibatan individu dalam suatu organisasi. Untuk mengukur komitmen organisasi, penelitian ini menggunakan indikator: komitmen afektif yang terdiri dari secara emosional perasaan terikat pegawai terhadap organisasi, keterlibatan pegawai dalam organisasi. Pengukuran berikutnya menggunakan indikator komitmen berkelanjutan yang terdiri dari perasaan pegawai jika meninggalkan organisasi, memiliki komitmen untuk bertahan, memikirkan risiko jika meninggalkan organisasi, serta memiliki pertimbanganpertimbangan untuk organisasinya. Indikator yang terakhir menggunakan komitmen normatif yang terdiri dari perasaan pegawai bertahan dalam organisasi, melaksanakan tugas dengan antusias dan penuh tanggungjawab, dan perasaan pegawai untuk mensukseskan organisasi.

Variabel independent ketiga adalah personal cost yang oleh Schultz et al. (1993) mendefinisikan sebagai risiko yang diterima oleh seseorang pelapor tindakan kecurangan yang berasal dari seseorang yang telah melakukan kecurangan. Variabel ini diukur dengan menggunakan model manipulasi dalam bentuk kasus cerita yang digunakan oleh Astuti (2016). Untuk mengukur variabel ini, responde diminta untuk menilai seberapa besar risiko yang dihadapi atas kasus yang diberikan.

Variabel independent yang keempat adalah tingkat keseriusan kecurangan. Schultz et al. (1993) mendefiniskan tingkat keseriusan kecurangan adalah persepsi pegawai atas seberapa besar tingkat kecurangan yang diukur berdasarkan variasi besarnya nilai kerugian akibat kecurangan yang terjadi. Variabel ini juga menggunakan model kasus yang dikembangkan oleh Astuti (2016) dengan menggunakan dua kasus. Kasus pertama menggambarkan kasus kecurangan belanja fiktif dan kasus kedua menggambarkan kasus kecurangan dengan cara mark-up realisasi belanja.

Skala likert 1 sampai 5 digunakan untuk pengukuran semua variabel dalam penelitian ini. Skala 1 menggambarkan sangat tidak setuju atau sangat tidak serius, dan skala 5 menggambarkan sangat setuju atau sangat serius.

\section{Populasi dan Sampel}

Populasi dalam penelitian ini adalah kepala sub bagian keuangan dan staf organisasi perangkat daerah kabupaten Jepara. Berdasarkan data dari web Jepara dan data yang diperoleh peneliti di lapangan, organisasi perangkat daerah di Jepara berjumlah 48 dengan 86 pegawai yang menduduki kepala sub bagian keuangan dan staf. Dengan menggunakan rumus Slovin, sampel diperoleh 60 responden dengan menggunakan simple random sampling.

\section{Metode Analisis Data}

Penelitian ini melakukan uji kualitas data dan uji asumsi klasik. Setelah data lolos dari uji kualitas data dan asumsi klasik, data dilakukan analisis dengan menggunakan analisis regresi linier berganda dengan SPSS (Statistical Product and Service Solution).

\section{Hasil dan Pembahasan}

Responden yang diolah dalam penelitian ini berjumlah 60 yang didapat dari jawaban kepala sub bagian keuangan dan salah satu stafnya. Dari beberapa jawaban tersebut, didapat statistic deskriptif sebagaimana di gambar 2. 


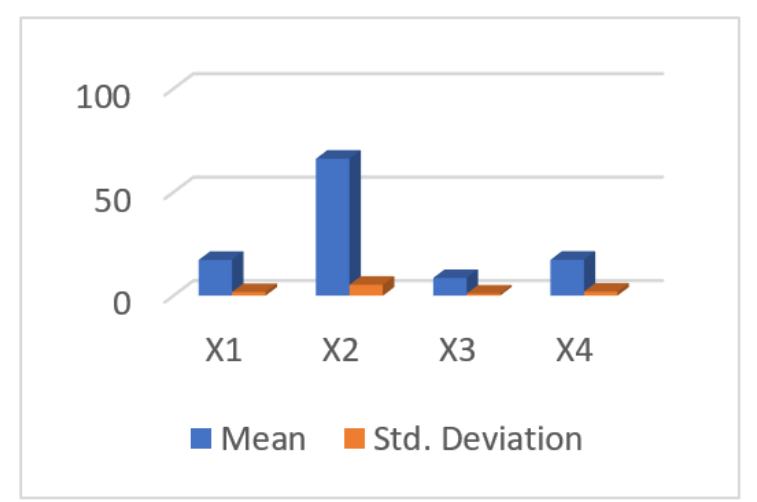

Gambar 2. Statistik Deskripftif

Berdasarkan gambar 2, rata-rata jawaban responden yang terkait dengan variabel sikap sebesar 17,25, variabel komitmen organisasi sebesar 66,17, variabel personal cost sebesar 8,53 dan variabel tingkat keseriusan kecurangan sebesar 17,32. Sedangkan standar deviasi masing-masing variabel adalah 1,762 untuk variabel sikap; 5,241 untuk variabel komitmen organisasi, 1.016 untuk variabel personal cost dan 1,944 untuk variabel tingkat keseriusan kecurangan.

Penelitian ini sudah melalui uji validitas dan reliabilitas, serta sudah melalui uji asumsi klasik. Semua data sudah valid dan reliabel serta sudah normal, bebas multikolonieritas, bebas heteroskedastisitas dan bebas autokorelasi. Selain itu, penelitian ini juga sudah menunjukkan model penelitian yang fit atau layak. Setelah melalui berbagai uji tersebut di atas, maka model regresi linier berganda dalam penelitian ini adalah:

$$
\begin{gathered}
Y=5,494+0,688 X_{1}+0,111 X_{2}-0,905 X_{3}+ \\
0,287 X_{4}+e
\end{gathered}
$$

Uji t dalam penelitian ini ditunjukkan dalam tabel 1 .

Tabel 1. Hasil Uji Regresi Linier Berganda

\begin{tabular}{|c|c|c|c|}
\hline \multirow[b]{2}{*}{ Model } & \multicolumn{3}{|c|}{ UnstandardizedStandardized } \\
\hline & B & $\begin{array}{l}\text { Std. } \\
\text { Error }\end{array}$ & Beta \\
\hline $\begin{array}{l}\text { (Constant) } \\
\text { Sikap }\end{array}$ & 5,498 & 2,632 & $2,089,041$ \\
\hline $\begin{array}{l}\text { Terhadap } \\
\text { Whistleblowing }\end{array}$ & ,688 &, 118 & $, 5475,849,000$ \\
\hline $\begin{array}{l}\text { Komitmen } \\
\text { Organisasi }\end{array}$ &, 111 & 040 & $, 2622,784,007$ \\
\hline Personal Cost &,- 905 & , 190 & $-, 415_{4,772}, 000$ \\
\hline $\begin{array}{l}\text { Tingkat } \\
\text { Keseriusan } \\
\text { Kecurangan }\end{array}$ & ,287 &, 100 & $, 2522,870,006$ \\
\hline a. Dependent & ariab & Mina & t Pegawai Melakukan \\
\hline
\end{tabular}
Coefficients $^{\mathrm{a}}$

Berdasarkan tabel 1 di atas, menunjukkan bahwa variabel sikap terhadap whistleblowing mempunyai t hitung sebesar 5,849 dengan probabilitas (sig) 0,000 . Nilai probabilitas (sig) ini kurang dari nilai $\alpha(0,000<0,05)$, sehingga variabel sikap terhadap whistleblowing berpengaruh positif signifikan terhadap minat pegawai melakukan tindakan whistleblowing. Dengan demikian hipotesis pertama (H1) diterima. Hasil ini menunjukkan bahwa dengan memiliki sikap yang baik terhadap whistleblowing responden berkeyakinan bahwa adanya tindakan ini akan berdampak positif terhadap keberlangsungan organisasi. Organisasi akan berjalan sesuai dengan tujuan yang diharapkan.

Hasil statistik deskriptif menunjukkan bahwa rata-rata jawaban responden tentang sikap terhadap whistleblowing adalah tinggi yaitu sebesar 17,25 dengan standar deviasi 1,762 yang rendah menunjukkan bahwa responden bersepakat sikap terhadap whistleblowing merupakan sesuatu hal yang positif, dimana dengan adanya whistleblowing maka praktek kecurangan atau tindakan ilegal yang dilakukan oleh atasan ataupun sesama teman kerja dapat diminimalisir. Tingginya tingkat pendidikan responden juga berpengaruh pada cara pandang responden terhadap suatu masalah menjadi lebih lebar. Responden beranggapan bahwa menjadi whistle-blower merupakan suatu tindakan yang positif bagi organisasi.

Hasil ini sejalan dengan Theory of Planned Behavior (TPB) yang menyatakan terdapat tiga determinan independen dari minat. Salah satu dari determinan itu adalah sikap, yaitu tingkatan dimana seorang pegawai menilai apakah perilaku tersebut baik untuk dilakukan atau tidak. Minat terhadap tindakan whistleblowing akan timbul apabila sikap terhadap whistleblowing tinggi. Seorang pegawai beranggapan bahwa menjadi whistleblowing akan dapat merubah tatanan suatu organisasi menjadi lebih baik, mereka akan beranggapan bahwa menjadi whistle-blower merupakan sesuatu yang baik, sehingga mereka berupaya mewujudkan minat tersebut ke dalam tindakan yang nyata. Hasil penelitian ini sesuai dengan penelitian yang dilakukan Bagustianto \& Nurkholis (2015) dan Sutrisni \& Coryanata (2018) menyimpulkan sikap terhadap whistleblowing berpengaruh positif terhadap minat melakukan whistleblowing.

Variabel komitmen organisasi mempunyai t hitung sebesar 2,784 dengan probabilitas (sig) 0,007. Nilai probabilitas (sig) ini kurang dari nilai $\alpha(0,007<0,05)$, sehingga variabel komitmen organisasi berpengaruh positif signifikan terhadap minat pegawai melakukan tindakan whistleblowing. Dengan demikian hipotesis dua $(\mathrm{H} 2)$ diterima. Hasil ini menunjukkan bahwa anggota organisasi yang memiliki komitmen organisasi yang tinggi, akan berusaha semaksimal mungkin untuk menjaga nama baik organisasi

Hasil statistik deskriptif menunjukkan bahwa rata-rata jawaban responden tentang komitmen organisasi adalah tinggi yaitu sebesar 66,17 dengan standar deviasi sebesar 5,241. Data tersebut menunjukkan responden bersepakat untuk memiliki komitmen organisasi yang tinggi. Rasa tanggung jawab yang kuat dan rasa memiliki organisasi akan mendorong seorang pegawai untuk mengungkapkan tindakan penyelewengan yang terjadi di organisasinya dengan berminat melakukan whistleblowing.

Prosocial organizational behavior theory menjelaskan bahwa tindakan seseorang terhadap organisasi dikarenakan 
adanya tujuan untuk meningkatkan kesejahteraan individu dan organisasi tersebut. Seorang anggota organisasi yang memiliki komitmen organisasi yang tinggi akan menjaga nama baik organisasi dan tidak akan bekerjasama dengan teman maupun atasan yang melakukan tindakan untuk keuntungan pribadi yang tidak sesuai dengan tujuan organisasi. Salah satu bentuk tindakan ini adalah minat melakukan tindakan whistleblowing. Dengan memiliki minat melakukan tindakan whistleblowing individu dalam organisasi berkeyakinan tindakan ini merupakan bentuk komitmen terhadap organisasi dan akan membuat organisasi akan berjalan dengan baik. Hasil penelitian ini sesuai dengan penelitian yang dilakukan oleh Bagustianto \& Nurkholis (2015) yang menemukan bahwa komitmen organisasi berpengaruh positif signifikan terhadap minat melakukan whistleblowing.

Variabel personal cost mempunyai t hitung sebesar $-4,772$ dengan probabilitas (sig) 0,000 . Nilai probabilitas (sig) ini kurang dari nilai $\alpha(0,000<0,05)$, sehingga variabel personal cost berpengaruh negatif terhadap minat pegawai melakukan tindakan whistleblowing. Dengan demikian hipotesis tiga (H3) diterima. Hasil ini menunjukkan bahwa variabel personal cost memiliki arah hubungan negatif terhadap minat minat pegawai melakukan tindakan whistleblowing.

Hasil statistik deskriptif menunjukkan rata-rata personal cost sebesar 8,53 adalah tinggi dengan standar deviasi 1,016. Data tersebut membuktikan bahwa responden sepakat bahwa tindak kecurangan harus segera dilaporkan. Hasil ini selaras dengan Theory of Planned Behavior (TPB) yang menyatakan bahwa minat (intention) lebih tepat dalam memprediksi perilaku aktual yang menghubungkan antara sikap dan perilaku. dimana besarnya persepsi personal cost sangat berpengaruh terhadap minat melakukan whistleblowing. Penelitian ini didukung oleh penelitian yang telah dilakukan Aliyah \& Marisan (2017) yang menemukan bahwa personal cost berpengaruh negatif terhadap minat pegawai melakukan tindakan whistleblowing.

Sedangkan variabel tingkat keseriusan kecurangan mempunyai t hitung sebesar 2,870 dengan probabilitas (sig) 0,006. Nilai probabilitas (sig) ini kurang dari nilai $\alpha$ $(0,006<0,05)$, sehingga variabel tingkat keseriusan kecurangan berpengaruh positif signifikan terhadap minat pegawai melakukan tindakan whistleblowing. Dengan demikian hipotesis empat (H4) diterima. Hasil ini menunjukkan bahwa semakin tinggi tingkat keseriusan kecurangan maka semakin tinggi pula minat minat pegawai melakukan tindakan whistleblowing.

Hasil statistik deskriptif menunjukkan bahwa rata-rata tingkat keseriusan kecurangan sebesar 17,31 dengan standar deviasi sebesar 1,944. Data tersebut menunjukkan bahwa responden bersepakat bahwa tingkat keseriusan kecurangan yang tinggi menyebabkan individu memiliki tanggung jawab untuk melindungi organisasinya dari kerugian. Tingginya keseriusan kecurangan ini akan berdampak tidak baik terhadap organisasi. Anggota yang melihat tingkat keseriusan kecurangan sangat tinggi ini akan berupaya untuk mencegah ataupun meminimalisir tindakan tersebut dengan jalan melakukan whistleblowing.
Hasil ini sesuai dengan prosocial organizational behavior theory yang menjelaskan bahwa melindungi organisasi dari bahaya merupakan salah satu perilaku prosocial. Kecurangan yang berdampak besar pada organisasi akan mendorong anggota organisasi untuk melindungi organisasi dengan cara mengungkapkan kecurangan tersebut pada pihak yang berwenang dengan menjadi whistle-blower. Dengan menjadi whistle-blower mereka beranggapan dapat menjadi penyelamat organisasi yang telah memberikan mereka penghidupan. Hasil penelitian ini sesuai dengan penelitian yang dilakukan oleh Aliyah \& Marisan (2017) dan Bagustianto \& Nurkholis (2015) yang menemukan bahwa tingkat keseriusan kecurangan berpengaruh positif signifikan terhadap minat pegawai melakukan tindakan whistleblowing.

\section{Simpulan Penelitian}

Sikap terhadap whistleblowing, komitmen organisasi dan tingkat keseriusan kecurangan berpengaruh positif signifikan terhadap minat pegawai melakukan tindakan whistleblowing. Sedangkan personal cost berpengaruh negatif terhadap minat pegawai melakukan tindakan whistleblowing. Sikap terhadap whistleblowing yang ditunjukkan dengan tingginya respon pegawai untuk melakukan whistleblowing, maka semakin tinggi minat pegawai melakukan tindakan whistleblowing.

Semakin tinggi komitmen organisasi yang ditunjukkan denga tumbuhnya keyakinan pagawai bahwa tindakan whistleblowing dapat melindungi organisasi dari kehancuran, maka semakin tinggi minat pegawai melakukan tindakan whistleblowing. Selain itu, semakin tinggi tingkat keseriusan kecurangan yang harus dilaporkan agar organisasi tidak mengalami kerugian, maka semakin tinggi pula minat pegawai melakukan tindakan whistleblowing. Namun, personal cost yang ditunjukkan dengan besarnya dampak melakukan whistleblowing terhadap diri pegawai, maka akan mengurangi minat pegawai untuk melakukan tindakan whistleblowing.

\section{Implikasi Penelitian}

Implikasi penelitian ini adalah minat seseorang melakukan whistleblowing didorong oleh sikap, komitmen seseorang di organisasi, personal cost dan tingkat keseriusan kecurangan. Selain itu, penelitian ini digunakan sebagai masukan bagi pemerintah untuk memperhatikan aspek pendorong seseorang untuk mempunyai minat melakukan whistleblowing di lembaga pemerintahan.

\section{Referensi}

Ajzen, I. (1991). The Theory of Planned Behavior. Organizational Behavior and Human Decision Processes, 50, 179-211.

Aliyah, S., \& Marisan, I. (2017). Analisis Faktor-Faktor yang mempengaruhi Minat Pegawai Melakukan Tindakan WhistleBlowing dengan Reward Model sebagai Variabel Moderating. Jurnal Dinamika Ekonomi Dan Bisnis, 14(1), 96-117. 
Astuti, Y. P. (2016). Pengaruh Sikap Whistleblowing, Komitmen Organisasi, Personal Cost, Tingkat Keseriusan Kecurangan dan Sensitivitas Etis Terhadap Minat Pegawai Negeri Sipil (PNS) untuk Melakukan Tindakan Whistleblowing. Universitas Muria Kudus.

Bagustianto, R., \& Nurkholis. (2015). Faktor-faktor yang mempengaruhi Minat Pegawai Negeri Sipil (PNS) untuk Melakukan Tindakan Whistle-Blowing (Studi Pada PNS BPK RI). Jurnal Ilmiah Mahasiswa FEB Universitas Barwijaya, 3(1).

Brief, A., \& Motowidlo, S. J. (1986). Prosocial Organizational Behaviors. The Academy of Management Review, 11(April), 710-725. https://doi.org/10.2307/258391

Iskandar, A., \& Saragih, R. (2018). The Influence Of Attitude Toward The Behavior, Subjective Norms, And Perceived Behavioral Control On WhistleBlowing Intention And Behavior of CPNS. Jurnal Tata Kelola \& Akuntabilitas Keuangan Negara, 4(1), 63-84.

Kumar, M., \& Santoro, D. (2017). A justification of whistleblowing. Philosophy and Social Criticism, $X X(\mathrm{X}), \quad 1-16$. https://doi.org/10.1177/0191453717708469

Meyer, J. P., Bobocel, D. R., \& Allen, N. J. (1991). Development of Organizational Commitment During The First Year of Employment: A Longitudinal Study of Pre- and Post-Entry Influences. Journal of Management, 17(4), 717-733.

Miceli, M. P., Near, J. P., \& Schwenk, C. R. (1991). Who Blows the Whistle and Why? Industrial and Labor Relations Review, 45(1), 113-130.

Mowday, R. T., Steers, R. M., \& Porter, L. W. (1979). The Measurement of Organizational Commitment. Journal of Vocational Behavior, 14, 224-247.

Oktavia, E. (2018). Pengaruh Personal Cost, Komitmen Organisasi, Sensitivitas Etis dan Machiavellian terhadap Minat melakukan Whistleblowing. JOM FEB, 1(1), 1-15.

Park, H., \& Blenkinsopp, J. (2009). Whistleblowing as Planned Behavior - A Survey of South KoreanPolice Officers Park , H . and Blenkinsopp , J . ( 2009 )' Whistleblowing as planned behavior - A survey of South Korean police officers. Journal of Business Ethics, 85(April), 545-556. https://doi.org/10.1007/s10551-008-9788-y

Schultz, J. J., Johnson, D. A., Morris, D., \& Dyrnes, S. (1993). An Investigation of the Reporting of Questionable Acts in an International Setting. Journal of Accounting Research, 31, 75-103.

Secord, P. F., \& Backman, C. W. (1964). Social Psychology. German: McGraw-Hill.

Sutrisni, D., \& Coryanata, I. (2018). Faktor-faktor yang Mempengaruhi Minat Pengelola Keuangan Melakukan Tindakan Whistle-Blowing. Jurnal Akuntansi, 8(1), 41-53.

Zubaidah, S. (2019). Whistleblowing Intention: Pengaruh Komitmen Organisasi, Personal Cost, Sikap, Kontrol Perilaku dan Peran Moderasi Dukungan Organisasi. STIE Perbanas. 